\title{
Brygida Pawłowska-Jądrzyk*
}

(iD) https://orcid.org/0000-0001-9900-2070

\section{Swojskie przestrzenie absurdu}

\author{
Streszczenie
}

Przedmiotem analizy w artykule jest Przemiana (1915) Franza Kafki. Autorka podejmuje próbę uchwycenia różnorodnych aspektów fenomenu przestrzeni kafkowskiej w kontekście funkcjonowania motywu murów/ścian/sufitów w tym bodaj najsłynniejszym opowiadaniu literatury światowej. Badaczka traktuje przy tym utwór Kafki jako niedościgniony wzór artystycznego kształtowania scenerii: takiego mianowicie, które plastyczność i konkret motywów oraz relacji przestrzennych czyni swego rodzaju residuum wysublimowanych, symbolicznych znaczeń, realizujących się w pełni dopiero za pośrednictwem wyobraźni odbiorcy, w toku kontemplacyjnej lektury i towarzyszącego jej przeżycia estetycznego. Wywód prowadzi do konkluzji, że Kafka w swym parabolicznym, absurdalnym, pełnym niedopowiedzeń (a jednak zaskakująco konkretnym) opowiadaniu nie odsłania sensu historii bohatera przemienionego w stawonoga, pozwala nam jednak ten sens przeżyć i przeczuć - jako treść naszego własnego życia.

Słowa kluczowe: Franz Kafka, Przemiana, metamorfoza, proza groteskowa, absurd, wyobraźnia artystyczna, przestrzeń przedstawiona, parabola, symbol

Niniejszy szkic stanowi próbę nakreślenia potencjału symbolicznego motywu murów/ścian w kontekście Przemiany Franza Kafki¹. Utwór ten uważany bywa za jed-

* Prof. ucz. dr hab., Uniwersytet Kardynała Stefana Wyszyńskiego w Warszawie, Wydział Nauk Humanistycznych, Instytut Nauk o Kulturze i Religii, Katedra Poetyki Intersemiotycznej i Komparatystyki Mediów, ul. Dewajtis 5, 01-815 Warszawa; e-mail: brygida.pawlowska@gmail.com

1 Do tego niezapomnianego dzieła wracam po latach, dążąc do uwypuklenia w nim coraz to innych aspektów nowatorstwa (por. mój pierwszy szkic o opowiadaniu Kafki, który został zogniskowany wokół problemu szeroko pojętej eliptyczności tego utworu: B. Pawłowska-Ją- 
no ze szczytowych osiągnięć prozy światowej, może on być jednak także uznany za niedościgniony wzór a r t y s t y c z n e g o kształtowania scenerii: takiego mianowicie, które plastyczność i konkret motywów oraz relacji przestrzennych czyni swego rodzaju residuum wysublimowanych, głębokich i złożonych znaczeń naddanych, realizujących się w pełni dopiero za pośrednictwem wyobraźni, w toku kontemplacyjnej lektury i towarzyszącego jej przeżycia estetycznego. Kafkowska Przemiana zdaje się zaświadczać, że na obszarze sztuki poprzez misterną symbiozę „namacalnego” szczegółu i efemerycznych treści przenośnych absurd wpisany w ludzką egzystencję wyraża się nadzwyczaj sugestywnie i, nomen omen, szczególnie dotkliwie ${ }^{2}$.

\section{Od naturalności do niezwykłości}

Vladimir Nabokov, wybitny pisarz i zarazem wielki admirator opowiadania Kafki, podkreśla w jednym ze swoich wykładów: „[...] musimy pamiętać, że literatura to nie zestaw i d e i , lecz określony system o b r a z ó w. Idee nie znaczą wiele w zestawieniu z artystyczną wizją autora i z magią książki"3.

Fenomen Przemiany (Die Verwandlung, 1915) ${ }^{4}$ bez wątpienia opiera się właśnie na sugestywności autorskiej wizji. Co znamienne, wizję tę współtworzą heterogeniczne komponenty opowiadania, w tym między innymi: narracyjna technika przemilczeń czy niedomówień (styl „drugiego planu”) ${ }^{5}$ i zaskakująca konkretność niezwykłych przedstawień, estetyczne pierwiastki absurdu, groteski, ironii, komizmu

drzyk, Strategie pisarskie. „Przemiana”, [w:] Poetyka egzystencji. Franz Kafka na progu XXI wieku, red. E. Kasperski, T. Mackiewicz, Wydawnictwo Uniwersytetu Warszawskiego, Warszawa 2004, s. 127-146). W niniejszym artykule zasadniczo podtrzymuję swoje wcześniejsze opinie na temat kształtu artystycznego Przemiany i jego konsekwencji interpretacyjnych, starając się w sposób wieloaspektowy i możliwie systematyczny uchwycić problem różnorodnych aspektów fenomenu przestrzeni kafkowskiej w kontekście funkcjonowania motywu murów/ ścian w Przemianie.

2 Nie mam tu na uwadze wyłącznie twórczości literackiej ani też tylko stricte groteskowej, jak w przypadku prozy Kafki. Por. np.: B. Pawłowska-Jądrzyk, Haneke w polu kontekstów fakultatywnych. "Miłość" z Kafka w tle, [w:] Rozjaśnianie Hanekego, red. B. Pawłowska-Jądrzyk, K. Taras, Wydawnictwo Naukowe UKSW, Warszawa 2019, s. 167-186.

3 V. Nabokov, Anna Karenina, [w:] tegoż, Wykłady o literaturze rosyjskiej, przeł. Z. Batko, Wydawnictwo Muza, Warszawa 2002, S. 221 (podkreślenie - autora).

4 Przemiana ukazała się najpierw w piśmie „Die Weißen Blätter” 2. Jg., Heft 10 (Oktoberheft 1915), s. 1177-1230, redagowanym przez René Schickele, następnie, w listopadzie 1915 r., w wydawnictwie Kurta Wolffa w Lipsku, w serii Der Jüngste Tag, jako numer podwójny 22/23 (na karcie tytułowej umieszczono rok 1916).

5 Por. B. Pawłowska-Jądrzyk, Strategie pisarskie. „Przemiana”, s. 141-143. 
i tragizmu ${ }^{6}$, momenty niemal beztroskiego zapomnienia i ciężki, klaustrofobiczny klimat osaczenia, upiornej mistyfikacji. Nabokov, który rozpatruje Przemianę w kontekście twórczości Nikołaja Gogola (Płaszcz) oraz Roberta Louisa Stevensona (Doktor Jekyll i pan Hyde), szczególnie akcentuje paradoksalne rysy w kreacji protagonisty opowiadania. Zdaniem autora Lolity kunszt Kafki przejawia się

[...] w nagromadzeniu z jednej strony owadzich cech, wszystkich przygnębiających detali owadziej powłoki Gregora, a z drugiej w zachowaniu żywego i niezmąconego obrazu jego ujmującej i subtelnej ludzkiej natury?

Z kolei egzystencjalista Albert Camus w następujący sposób określa ten utwór, naświetlając zarazem istotę fenomenu całej spuścizny praskiego pisarza:

Przemiana [...] jest przerażającą figurą moralności, która wynika z jasności widzenia. Ale jednocześnie jest rezultatem niewypowiedzianego zaskoczenia, którego doświadcza człowiek czując, jak bez wysiłku staje się zwierzęciem. W tej fundamentalnej dwuznaczności kryje się sekret Kafki. Nieustanne przejścia od naturalności do niezwykłości, od tego, co indywidualne, do tego, co powszechne, od tragiczności do codzienności, od absurdu do logiki można odnaleźć w całym dziele Kafki; w nich siła tego dzieła i jego znaczenie. Aby dzieło absurdalne stało się zrozumiałe, paradoksy te trzeba wyliczać i podkreślać sprzeczności ${ }^{8}$.

6 „W świecie k a f k o w s k i m komizm nie tworzy kontrapunktu dla tragizmu (tragikomizm), jak to się dzieje u Szekspira. Nie pojawia się w nim, by dzięki lekkości tonu uczynić bardziej znośnym to, co tragiczne; nie t o w a r z y s z y tragizmowi, n i s z c z y g o w z a r o d k u, pozbawiając $w$ ten sposób ofiarę jedynego pocieszenia, którego mogłaby jeszcze oczekiwać: pocieszenia, jakie przynosi wzniosłość [...] tragedii”. M. Kundera, Sztuka powieści, przeł. M. Bieńczyk, "Czytelnik”, Warszawa 1998, s. 95; podkreślenia - autora. Por. E. Kasperski, Tragigroteska Kafki, „Tekstualia” 2008, nr 3, s. 19-34.

7 V. Nabokov, Wykłady o literaturze, przeł. Z. Batko, Wydawnictwo Muza, Warszawa 2001, s. 348. Zgodnie z konkluzją Nabokova, Gregor jawi się jako istota ludzka o powierzchowności owada, jego rodzina zaś „to insekty o powierzchowności ludzi” (tamże, s. 360). Nabokov, znany z fascynacji owadami, podjął próbę spojrzenia na bohatera Przemiany z punktu widzenia zoologii. Analiza sceny, w której Gregor stara się obrócić klucz w zamku, doprowadziła autora Lolity do wniosku, że Kafkowski żuk musiałby mieć mniej więcej metr długości. Nawiasem mówiąc, scena ta stanowiła jedną z inspiracji twórczych dla legendarnego rysownika "Przekroju” Daniela Mroza, zob. „Przekrój” 1956, nr 576; J. Kwiatkowski, Daniel Mróz, Wydawnictwo Literackie, Kraków 1961.

8 A. Camus, Nadzieja i absurd w dziele Franza Kafki, [w:] tegoż, Mit Syzyfa i inne eseje, przeł. J. Guze, Wydawnictwo Muza, Warszawa 1999, s. 152. Por.: W. Rainczak, Logiczność absurdu w twórczości Franza Kafki na podstawie „Przemiany” i „Procesu”, [w:] Komentarze do Kafki, red. B. Małczyński, J. Furmaniak, Wydawnictwo Chiazm, Wrocław 2007, s. 71-76. 


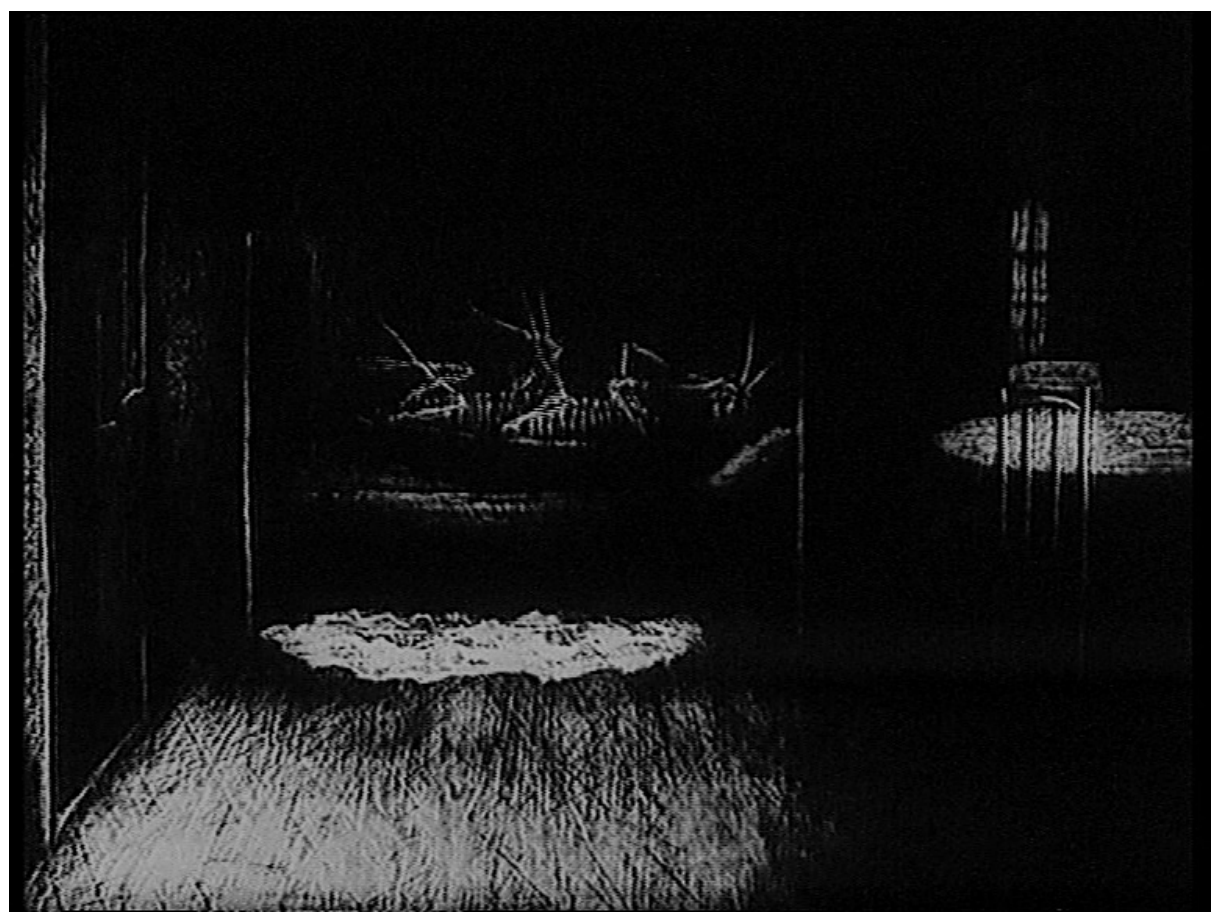

Fot. 1. Piotr Dumała podkreśla w swojej animacji mroczny wymiar świata przedstawionego Przemiany (inaczej niż np. Daniel Mróz, który raczej uwypuklał w nim baśniowość). Kadr z filmu Piotra Dumały pt. Franz Kafka (1991)

\section{Groteskowy dramat „wśród czterech dobrze znanych ścian”}

Już przed wieloma laty zauważono, że Kafka czyni wszystko, by uniemożliwić odczytanie Przemiany jako baśni, horroru, nadprzyrodzonej fantastyki czy wizji sennej’. Służy temu między innymi umiejscowienie dramatu głównego bohatera w banalnej scenerii jego rodzinnego mieszkania, a nie w przestrzeni obcej, nierozpoznanej, jaką stanowią na przykład zamorski ląd (w powieści przygodowej) czy las (w konwencji baśniowej). „Ontologiczny skandal” rozgrywający się w czterech ścianach pokoju Gregora Samsy - tak niewyobrażalny, a zarazem tak silnie utwierdzony w powszedniości - domaga się od czytelnika interpretacji parabolicznej i wywołuje zgrozę; wszak nie chodzi o bardzo odległe czy wyimaginowane krainy, ale o nas z włas n y ś wi at, którego pewność i stabilność niespodzianie okazują się tylko złudzeniem ${ }^{10}$.

9 P. Thomson, The Grotesque, Published by Methuen \& Co Ltd., London 1972, s. 7-8.

10 Przemianę z powodzeniem można interpretować za pomocą Kayserowskiej koncepcji groteskowości: „[...] groteskowość to świat, który stał się obcy. Przydadzą 
Szokujące odkrycie Samsy w ekspozycji opowiadania (bohater Kafki budzi się z męczących snów, by stwierdzić, że jest ogromnym stawonogiem) to dla niego przede wszystkim doznanie skrajnej inkongruencji tożsamości i sposobu własnego przejawiania się ${ }^{11}$. Co znamienne, po przebudzeniu się ${ }^{12}$ Gregor-robak, zanim pogrąży się we wspomnieniach, rozgląda się po ścianach swojego pokoju, próbując znaleźć grunt dla odbudowy własnej tożsamości poprzez identyfikację z miejscem:

Gdy Gregor Samsa obudził się pewnego rana z niespokojnych snów, stwierdził, że zmienił się w łóżku w potwornego robaka. Leżał na grzbiecie twardym jak pancerz, a kiedy uniósł nieco głowę, widział swój sklepiony, brązowy, podzielony sztywnymi łukami brzuch, na którym ledwo mogła utrzymać się całkiem już ześlizgująca się kołdra. Liczne, w porównaniu z dawnymi rozmiarami żałośnie cienkie nogi migały mu bezradnie przed oczami.

„Co się ze mną stało?” - myślał. To nie był sen. Jego pokój, prawdziwy, nieco tylko zbyt mały ludzki pokój, mieścił się spokojnie wśród czterech dobrze znanych ścian. Nad stołem, na którym rozpościerała się rozpakowana kolekcja towarów tekstylnych - Samsa był komiwojażerem - wisiał obraz, wycięty przez niego niedawno z ilustrowanego czasopisma i umieszczony w ładnej pozłacanej ramce (s. 21) ${ }^{13}$.

się tu wszakże jeszcze pewne objaśnienia. Świat baśni, gdy patrzy się nań z zewnątrz, dałoby się określić jako obcy i niezwykły. W istocie nie jest to jednak świat, który naprawdę stał się obcy. Nic bowiem, co było swojskie i znane, nie objawia się tu jako obce i tajemnicze. To nasz własny świat, tyle że uległ przeobrażeniom. [...] Zgroza przejmuje nas tak bardzo właśnie dlatego, że chodzi o nasz świat, którego pewność stała się pozorem. Czujemy zarazem, że w owym odmienionym świecie nie moglibyśmy żyć. W przypadku groteskowości nie chodzi o lęk przed śmiercią, ale o lęk przed życiem. Jej cechą strukturalną jest ujawnienie zawodności kategorii naszej orientacji w świecie". W. Kayser, Próba określenia istoty groteskowości, przeł. R. Handke, „Pamiętnik Literacki” 1979, z. 4, s. 276-277; podkreślenie - autora.

11 Nawiasem mówiąc, jaskrawo heterogeniczny charakter tej relacji prowadzi do efektu wyobraźniowego kojarzącego nową powierzchowność Gregora z ideą przebrania (maskarada, upozorowanie życia), która przykuła uwagę Henri Bergsona w części jego klasycznego eseju poświęconego zjawisku komizmu. Por. H. Bergson, Śmiech. Esej o komizmie, przeł. S. Cichowicz, Wydawnictwo KR, Warszawa 1995, s. 33 i nast.

12 Scena przebudzenia się głównego bohatera rozpoczyna także inicjalną część W poszukiwaniu straconego czasu (1913) czy Ferdydurke (1937). Dla Marcela Prousta i Witolda Gombrowicza motyw ten stanowi punkt wyjścia do artystycznej eksploracji doświadczenia dezintegracji świadomości, przy czym w pierwszej z wymienionych powieści stan ten ma charakter chwilowy i daje się przezwyciężyć dzięki scalającej mocy pamięci, w drugiej zaś zostaje ukazany jako przejaw nieuniknionej relatywizacji tożsamości, która, zgodnie z koncepcją polskiego pisarza, dokonuje się w procesie interakcji społecznej.

13 Wszystkie fragmenty Przemiany cytuję według przekładu Juliusza Kydryńskiego za następującym wydaniem: F. Kafka, Cztery opowiadania. List do ojca, przeł. J. Kydryński, J. Ziółkowski, Państwowy Instytut Wydawniczy, Warszawa 2003. 
Dezorientację i ograniczenie władz poznawczych Gregora Kafka akcentuje za pomocą motywu mgły: rzecz dzieje się o siódmej rano, gdy poranna rosa tak gęsto spowija okolice mieszkania Samsów, że monstrualny robak nie jest w stanie dostrzec z okna przeciwnej strony wąskiej ulicy, gdzie znajduje się szpital. Spokojnie kontemplując swoją nową fizjonomię oraz wygląd dobrze znanego lokum, Gregor nie powątpiewa ani przez chwilę, że w istocie swej jest człowiekiem, pozostał nadal s o b ą, wystarczy tylko trochę poczekać, by powróciły „rzeczywiste i zrozumiałe stosunki” (s. 28). Jego postawę cechuje niepojęta wręcz „niefrasobliwość”: Gregor nie złorzeczy, nie docieka przyczyn własnego losu, nie próbuje uwierzyć w żadne uzasadnienie ani też niczego zrozumieć ${ }^{14}$. To naprawdę intrygujące i osobliwe, że Kafkowski nieszczęśnik obserwuje swój brązowy, podzielony sztywnymi łukami brzuch oraz liczne odnóża i nie pyta „dlaczego? za co ta kara?”.

Lektura dzieła Kafki, w oryginalny sposób przetwarzającego motyw archetypowy, nie prowadzi do wypełnienia luk po konwencjonalnych rozwiązaniach fabularnych i wskazania koherentnych ciągów znaczeń czy klarownych odniesień aksjologicznych. W Przemianie przede wszystkim brak jest określenia determinant konfliktu wyjściowego - można rzec, iż psychologicznej redukcji postaci odpowiada tu w aspekcie fabularnym chwyt elipsy w sferze motywacji zdarzeń ${ }^{15}$. Konsekwencją takiego stanu rzeczy jest poniekąd unik aksjologiczny, jako że związek zjawiska przemiany z wartościami określa się właśnie przez jego genezę, przyczynę lub motywację ${ }^{16}$. Taka konstrukcja w zasadzie uniemożliwia określenie w kategoriach pozytywnych prawidłowości rządzących rzeczywistością przedstawioną.

Problemu sprawstwa własnego upadku nie ignorują natomiast inni protagoniści Kafki. Józef K. z Procesu, w swym „śmiesznym zaślepieniu”17, podejmuje usilne

14 Wiele utworów baśniowych traktuje o osobach zaklętych w zwierzę, ale w zasadzie wszystkie z nich w ten czy inny sposób określają przyczynę metamorfozy: wskazują na jej p o w ó d bądź s p r a w c ę. W baśniach zazwyczaj zostaje uwydatniony moment rozpoznania, w którym to, co wydawało się zwierzęce - odwrotnie niż w Przemianie - odsłania się nagle jako źródło ludzkiego szczęścia. Zob. B. Bettelheim, Cudowne i pożyteczne. O znaczeniach i wartościach baśni, przeł. i oprac. D. Danek, Wydawnictwo W.A.B., Warszawa 1996, s. 114-124, 427-475.

15 Więcej na ten temat w: B. Pawłowska-Jądrzyk, Strategie pisarskie. "Przemiana”, dz. cyt., s. $131-136$.

16 M. Gołaszewska, O zjawisku przemiany, [w:] Nauka o pięknie. Rozprawy z pogranicza estetyki, aksjologii ogólnej i antropologii filozoficznej, red. M. Gołaszewska, Wydawnictwo Uniwersytetu M. Curie-Skłodowskiej, Kraków-Lublin 1990, s. 53. Trzeba jednak zaznaczyć, że utwór Kafki „z całą bezwzględnością” stawia czytelnika wobec p o w a g i przedstawionej sytuacji aksjologicznej (por. A. Tyszczyk, Estetyczne i metafizyczne aspekty aksjologii literackiej Romana Ingardena, Lublin 1993, s. 78).

17 B. Schulz uznaje, że Kafka przez ukazanie desperackich dążeń Józefa K. ośmiesza beznadziejność poczynań ludzkich w stosunku do porządku boskiego (tenże, Posłowie do polskiego 
próby odnalezienia siedziby sądu, który osacza go za pomocą anonimowej machiny biurokratycznej. Również geometra K. w Zamku z uporem usiłuje sforsować niewidzialną barierę odgradzającą go od nieosiągalnego zleceniodawcy. Natomiast Gregor Samsa zachowuje się tak, jakby kwestia przyczyn czy uwarunkowań aktualnie doświadczanego dramatu nie stanowiła żadnego problemu, a jego myśli i działania ukierunkowane są ku determinantom fizjologicznym i - jak dawniej - ku trywialnym stronom bytowania ${ }^{18}$. Między innymi dlatego w Przemianie, będącej niewątpliwie jednym z najmroczniejszych dzieł literatury światowej, możliwe są paroksyzmy komizmu i lekkości.

\section{Rewiry zapomnienia - obszary doświadczania upadku. Metamorfozy przestrzeni w świecie przedstawionym Przemiany}

Niektórzy badacze skłaniają się ku opinii, że metafora człowieka jako nędznego robaka nie posiadałaby uzasadnienia poza perspektywą istoty boskiej, odczytując opowiadanie Kafki poprzez konteksty biblijne (Psalmy, Księga Hioba, Księga Izajasza): „w Przemianie fizjologia prowadzi nieoczekiwanie do metafizyki. Gregor Samsa, zamieniony w robaka, odkrywa - tak jak Plotyn i jego naśladowcy - że ciało jest więzieniem bytu”19. Trzeba jednak zaznaczyć, że ów „konflikt między pokraczną formą a duchową treścią" zostaje przez Kafkę przedstawiony za pomocą stylu epatującego błazeńskim wręcz weryzmem i hiperbolicznie spotęgowany (absurdalne w swojej istocie „zatrzaśnięcie” Gregora w pancerzu stawonoga znajduje swego rodzaju przedłużenie w uwięzieniu go przez rodzinę w „klatce” jego własnego pokoju).

Własną metamorfozę w budzącego odrazę owada były komiwojażer postrzega zrazu w kategoriach „lekkiej niedyspozycji” („nie czuł się szczególnie świeży i rześki”, s. 23) i wiąże ją także z pewnymi - by tak rzec - przywilejami bycia istotą posiadającą czułki. Fragment, w którym Gregor pełza dla rozrywki po ścianach

przekładu „Procesu” Franza Kafki [1936], [w:] tegoż, Szkice krytyczne, opracowanie i posłowie M. Kitowska-Łysiak, Wydawnictwo UMCS, Lublin 2000, s. 23).

18 Wątki te akcentują badacze dopatrujący się w opowiadaniu Kafki krytyki egzystencji mieszczańskiej i idei egzystencjalnej winy, grzechu przeciwko samemu sobie. Na przykład Marek Wydmuch uważa, że „przemiana to tylko akt zewnętrzny, krystalizacja sposobu życia, który z Gregora Samsy czynił myślące zwierzę. Poza nim samym nic nie zmieniło się w tym świecie, a i on odsunięty został jedynie od aktywności, zamknięty w nowym ciele, a nie przemieniony od samych podstaw swej egzystencji. [...]” (M. Wydmuch, Franz Kafka, „Czytelnik", Warszawa 1982, s. 35 i nast.). Refleksja tego rodzaju prowadzona bywa po torach socjologicznych, psychologicznych, wreszcie biograficznych (koncepcje Waltera H. Sokela i H. Richtera).

19 J. Tomkowski, Robak, „Więż” 1982, nr 11/12, s. 49. 
i suficie, należy do najbardziej wzruszających i najpogodniejszych w opowiadaniu; nieliczne obrazy tego rodzaju stanowią w nim pewną (jedynie chwilową i złudną) przeciwwagę dla scen, w których charakterystyczna dla praskiego pisarza technika kształtowania przestrzeni prowadzi do efektu osaczenia, pułapki.

[...] W ciągu dnia Gregor nie chciał już ze względu na rodziców pokazywać się w oknie, lecz po kilku metrach kwadratowych podłogi nie mógł zbyt wiele pełzać, spokojne leżenie źle znosił nawet w nocy, jedzenie nie sprawiało mu już najmniejszej przyjemności, przyzwyczaił się więc dla rozrywki pełzać we wszystkich kierunkach po ścianach i suficie. Chętnie zwłaszcza wisiał na suficie; było to coś zupełnie innego niż leżenie na podłodze; oddychało się swobodniej, tułów kołysał się z lekka, a wśród szczęśliwej niemal zabawy, jaką Gregor znajdował tam w górze, mogło się zdarzyć, iż ku własnemu zaskoczeniu odrywał się i padał plackiem na podłogę. Ale teraz naturalnie o wiele lepiej panował już nad swoim ciałem niż dawniej i nawet przy tak poważnym upadku nie wyrządzał sobie krzywdy. Siostra natychmiast zauważyła nową zabawę, jaką Gregor sobie wynalazł - pełzając, zostawiał tu i ówdzie ślady swych lepkich nóżek - i wbiła sobie w głowę, by umożliwić Gregorowi pełzanie po jak największej przestrzeni, a więc usunąć meble, które w tym przeszkadzały, przede wszystkim komodę i biurko (s. 57-58).

Cecha „zamknięcia świata” łączy pisarstwo Kafki między innymi z twórczością Sławomira Mrożka, w którego utworach „bezradność ludzkiego kręcenia się w kółko" jest - zdaniem krytyki - głównym źródłem komizmu. Włodzimierz Maciąg, zestawiając Przemianę z opowiadaniem Z ciemności (tom Słoń, 1957), czyni na ten temat interesującą obserwację:

Warto zauważyć, że marionetkowość (źródło komizmu) nie znajduje miejsca w wizji Kafki; jakkolwiek Kafka również nie zakłada wyjścia, zakłada wszakże wyjątkowość postaci Gregora Samsy, zakłada jakby jego powołanie do rozpoznania sytuacji zamknięcia. Samsa jest pierwszy i jedyny, który przeżywa swoje zamknięcie w obcości, zamknięcie go wyodrębnia i podmiotowo intensy$\mathrm{f} \mathrm{i} \mathrm{k} \mathrm{u} \mathrm{j} \mathrm{e.} \mathrm{Narrator} \mathrm{Mrożka} \mathrm{przeciwnie:} \mathrm{im} \mathrm{silniej} \mathrm{wali} \mathrm{głową} \mathrm{w} \mathrm{mur,} \mathrm{tym} \mathrm{skwapli-}$ wiej chwyta się sprawdzonych frazesów, tym bardziej zanika w zjawiskach ${ }^{20}$.

Gregor jest stopniowo pozbawiany przez rodzinę ostatnich swoich małych radości: okaleczony przez ojca, nie jest już w stanie pełzać po suficie, a w końcu

20 W. Maciąg, Sławomir Mrożek - czyli świat zamknięty, [w:] tegoż, Nasz wiek XX: przewodnie idee literatury polskiej 1918-1980, Ossolineum, Wrocław 1992, s. 282; podkreślenie - B.P.J. Zob. też: A. Morawiec, Konstrukcja i znaczenie przestrzeni przedstawionej w powieściach Franza Kafki, Wydawnictwo Uniwersytetu Łódzkiego, Łódź 2000. 
- dostrzeżony przez sublokatorów podczas jednego z popisów muzycznych siostry, których wieczorami zwykł z lubością wysłuchiwać przez uchylone drzwi do salonu - zostaje zatrzaśnięty i zaryglowany w pokoju-pułapce ${ }^{21}$, gdzie też - zaniedbany i niedożywiony - w końcu umiera (zdycha). Rodzina przyjmuje śmierć swojego byłego dobroczyńcy z ulgą i nieskrywanym zadowoleniem. Jak uogólnił tę kwestię Eleazar Mieletinski, w opowiadaniu Kafki tradycja mitologiczna zmienia się jakby we własne przeciwieństwo („[... Przemiana stanowi w pewnym sensie mit odwrócony, antymit, jeśli mit starożytny uznamy za pewnego rodzaju wzorzec") ${ }^{22}$. Według rosyjskiego mitoznawcy metamorfoza Samsy nie jest znakiem przynależności do rodowej wspólnoty, ale przeciwnie - „znakiem odłączenia, wyobcowania, konfliktu, zerwania więzi z rodziną i społeczeństwem"23.

W opowiadaniu Kafki niezwykle ważną rolę odgrywają metamorfozy przestrzeni, które - co istotne - idą w parze ze stopniową przemianą postaw postaci drugiego planu. (Myślę nie tylko o potęgującej się agresji wobec Gregora, której prawdziwa eksplozja następuje $\mathrm{w}$ wyniku zetknięcia się Samsów z „ludźmi z zewnątrz" - szczególną uwagę zwraca przedzierzgnięcie się siostry z troskliwej niegdyś opiekunki Gregora w jego najbardziej bezwzględnego prześladowcę - ale i o zaskakującej zaradności życiowej osób tak niegdyś nieporadnych, że „zmuszonych" do pozostawania przez całe lata na łasce dobrotliwego chlebodawcy.) Ujmując problem skrótowo: tragiczny los bohatera opowiadania wypełnia się z szybkością wprost proporcjonalną do zagracania jego lokum starymi, nikomu już niepotrzebnymi sprzętami. Z czasem pokój Samsy przekształca się w zaniedbaną rupieciarnię, w której funkcję ostatniego bastionu prywatności właściciela pełni stara kanapa. Jego przestrzeń życiowa ulega izolacji i sukcesywnemu zawężaniu²4,

21 Żaneta Nalewajk interpretuje Kafkowskie motywy miejsc-klatek, miejsc-pułapek w kontekście egzystencjalistycznego problemu samobójstwa. Badaczka dostrzega w nich „metafory egzystencji cechującej się gwałtownym ograniczeniem możliwości wyboru, egzystencji, którą można tylko albo przyjąć w całości (bez względu na to, jaka się okaże, jakie uwarunkowania napotka, jaka przemiana będzie jej ceną), albo w całości odrzucić, wyzbyć się pragnienia trwania, powiedzieć życiu i światu albo "tak" albo "nie»" (tejże, Ironia jako alternatywa rozpaczy. Krytyka kultury w „Sprawozdaniu dla Akademii”, „Tekstualia” 2008, nr 3, s. 68).

22 E. Mieletinski, Poetyka mitu, przeł. J. Dancygier, przedmowa M.R. Mayenowa, Państwowy Instytut Wydawniczy, Warszawa 1981, s. 437.

23 Tamże.

24 Odkrywamy tu kolejną różnicę między kreacją świata przedstawionego w Przemianie i w bajce. Przestrzeń bajkowa jest wręcz nieograniczona. Do jej maksymalnego rozszerzenia prowadzi „dynamiczna lekkość bajki” (zob. D.S. Lichaczow, Świat wewnętrzny dzieła literackiego, przeł. J. Faryno, „Pamiętnik Literacki” 1974, z. 4). Lekkość ta przejawia się m.in. w łatwości, z jaką porozumiewają się postacie - w tym, że zwierzęta mogą mówić, a drzewa rozumieć słowa bohatera (por. dramat komunikacyjny Gregora). 
co znajduje estetyczny wykładnik w doznaniu ciężkości, towarzyszącym lekturze ostatniej części utworu. Przemiana przestrzeni przedstawionej i związane z ową przestrzenią opozycje przestrzenne (góra - sufit, ściany; dół - podłoga) zyskują tu znaczenia naddane. Dotkliwie osamotnionemu Gregorowi przychodzi skonać w brudzie, w pomieszczeniu przypominającym śmietnisko, oddzielonym zaledwie ścianą od członków rodziny, którzy przez całe lata korzystali z jego ciężkiej pracy, a teraz odnoszą się do niego z wrogością i odrazą; wielki żuk, schorowany i „zakleszczony" na podłodze w odpadkach oraz w bezliku zbędnych przedmiotów, traci dostęp do ścian i sufitu, a także możliwość przemieszczania się w płaszczyźnie wertykalnej, ku górze.

Wstrząsająca historia człowieka przemienionego w stawonoga, tak sugestywnie rozegrana w sferze motywów przestrzennych, znajduje chyba najbardziej ironiczny, szyderczy wręcz kontrapunkt w zjawiskach będących w opowiadaniu emblematami przemian czasu. Gregor Samsa „zdycha” (z własnej niemalże woli, i nie bez uczucia ulgi) przy pierwszym brzasku świtu, w końcu marca, u progu budzącej wszystko do życia wiosny. Wzgardzone szczątki Gregora zostają usunięte z pokoju przez posługaczkę, bez udziału któregokolwiek z członków rodziny. W ropiejącej ranie na jego wychudzonym ciele tkwi jabłko - atrybut będący w kulturze europejskiej między innymi symbolem zdrowia, życia oraz doczesnych radości, a także odkupienia, nieśmiertelności i obecności boskiej... ${ }^{25}$

W niedalekim sąsiedztwie tej wizji Kafka kreśli sugestywny obraz siostry Gregora, Grety - dziewczyny pięknej, rozwiniętej i bujnej, niczym bogini płodności przeciągającej w słońcu swe młode ciało. Francuski pisarz i filozof Maurice Blanchot uznał finałową scenę Przemiany za wstrząsającą:

[Samsa] Umiera - śmierć nieznośna, w opuszczeniu i samotności, a jednak śmierć prawie szczęśliwa, bo daje uczucie wyzwolenia, przez nową nadzieję na koniec, teraz już ostateczny. Ale wkrótce z kolei ta ostatnia nadzieja okazuje się płonna; to nieprawda, nie było końca, egzystencja dalej trwa, a gest młodszej siostry, jej ruch budzenia się do życia, wezwanie do rozkoszy, którym kończy się opowiadanie, jest szczytem potworności. W całej tej opowieści nie ma nic bardziej przerażającego [... $]^{26}$.

25 W. Kopaliński, Słownik symboli, Wiedza Powszechna, Warszawa 1990, s. 112-113.

26 M. Blanchot, Wokół Kafki, przeł. K. Kocjan, Wydawnictwo KR, Warszawa 1996, s. 60-61. Nawiasem mówiąc, na podobieństwo finału dwóch opowiadań Kafki, Przemiany i Głodomora, zwróciła uwagę Maria Janion w szkicu poświęconym fascynacji Tadeusza Różewicza twórczością tego pisarza (zob. Przeraźliwość istnienia, [w:] tejże, Żyjąc tracimy życie, Wydawnictwo W.A.B., Warszawa 2001, s. 179-192). 


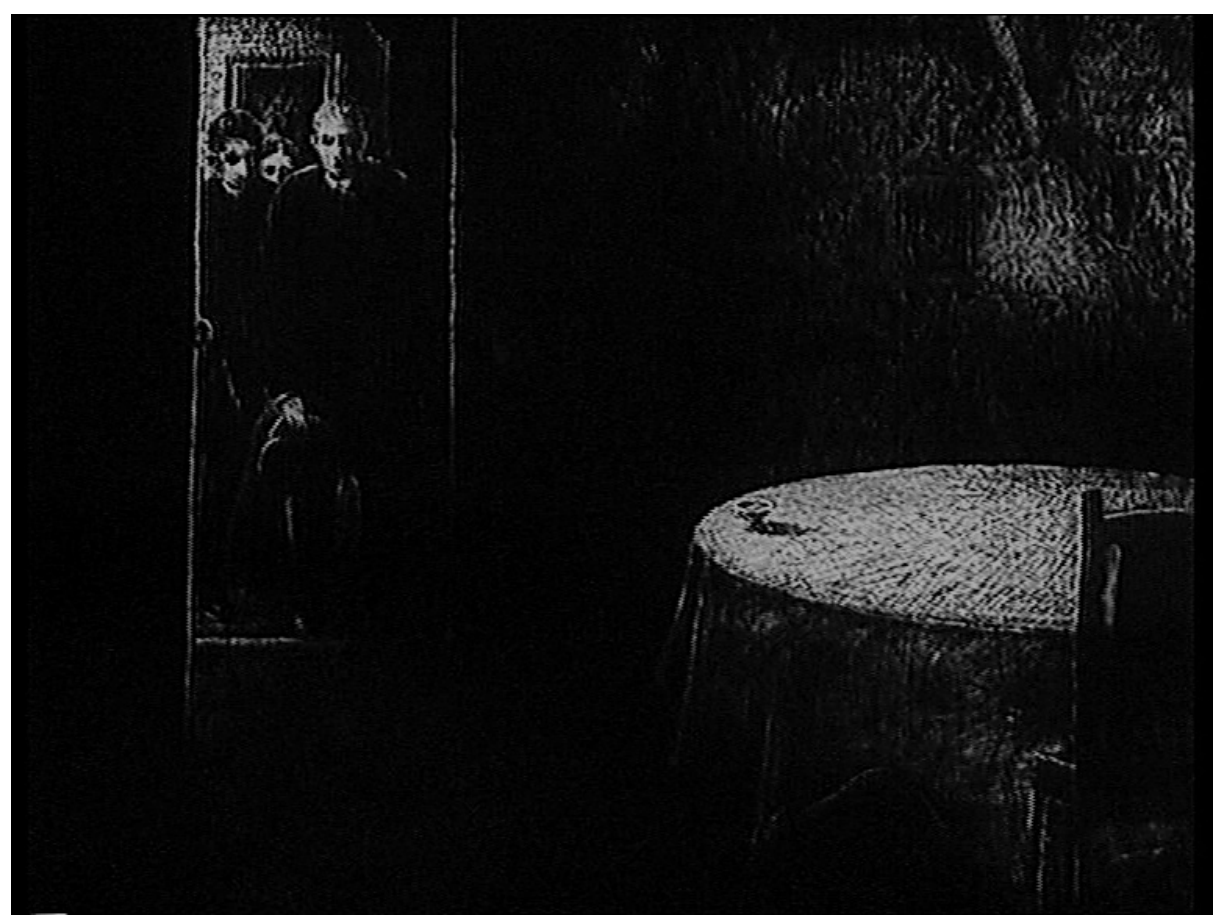

Fot. 2. Przemiana przyjmuje kształt formy fragmentarycznej i nierównomiernie oświetlonej, której właściwe są opisy kreślące zjawiska pobieżnie oraz wypowiedzi krótkie, oderwane, ostro ze sobą zderzone, spychające w mrok niedomówień fundamenty świata przedstawionego. Te cechy dzieła praskiego pisarza znakomicie wydobył Piotr Dumała w artystycznym filmie animowanym pt. Franz Kafka (1991)

\section{Motywy drzwi, ścian, sufitu, podłogi w Przemianie (słowo podsumowania)}

Jak już dowodziłam przy innych okazjach, Przemiana Kafki jest utworem, który zadręcza interpretatora niedosytem sensu, wzywając do odkrywania coraz to nowych zasad scalających. W zasadzie każdy pojawiający się w niej motyw symboliczny uzmysławia znaczeniowe rozwarstwienie przedstawionych sytuacji czy przewrotnie aluzyjny charakter tekstu. Na przykład styczność czasowa i domniemany związek wynikowy dwóch planów wydarzeń: ofiarnej (w pewnym ujęciu) śmierci Samsy ${ }^{27}$ oraz nadejścia „życiodajnej” wiosny zdają się odsłaniać metafi-

27 Można np. zaryzykować stwierdzenie, że historia Gregora Samsy - jeśli dopatrywać się w niej elementów parodii - jest dyskretnie stylizowana na starotestamentową opowieść o ofierze Abrahama. Abstrahując od konfiguracji postaci, można zauważyć, iż - poza podobieństwem techniki kształtowania rzeczywistości przedstawionej w obydwu tekstach 
zyczny i złowrogi wymiar przerażającej historii, kierują uwagę ku nieprzeniknionym mrokom istnienia, które gotują człowiekowi ostateczną zgubę. Nawet banalne, pozornie nieistotne czy przypadkowe elementy tła mogą stać się tu znakiem „zgubionego ogniwa”, kluczem do zasłoniętego sensu zdarzeń ${ }^{\mathbf{2 8}}$.

Nieszczęśnik zostaje zamieniony w insekta - i co z tego? Na tak zadane sobie pytanie Nabokov odpowiada:

Nie ma sensownej odpowiedzi na to „i co z tego?”. Możemy rozebrać historię na czynniki pierwsze, możemy się przyjrzeć, jak te cząstki są do siebie dopasowane, jak się ma jeden element mozaiki do drugiego, ale człowiek musi mieć w sobie pewną komórkę, pewien gen, który rozwibruje się w reakcji na doznania, trudne do zdefiniowania, ale też nie dające się zignorować. »Piękno plus litość« to najtrafniejsza definicja sztuki $[\ldots]^{29}$.

Jak wzmiankowałam na wstępie, Nabokov upatruje genialności Przemiany w zderzeniu precyzyjnego stylu ze śmiałością wizji ${ }^{30}$, w sposobach, w jakie opowiadanie to pobudza emocje i wyobraźnię odbiorcy, igrając pierwiastkami fantazji i realności.

- do zestawienia tego prowokują znamienne elementy tła (m.in. motyw świtu, o którym kiedyś interesująco pisał Erich Auerbach), a nade wszystko dwa najbardziej intrygujące „węzły problemowe", ukierunkowujące lekturę obydwu opowieści: milcząca zgoda na ogrom niezawinionego cierpienia i nieogarnialność przyczyn straszliwych doświadczeń człowieka. Por.: E. Auerbach, Blizna Odyseusza, [w:] tegoż, Mimesis. Rzeczywistość przedstawiona w literaturze Zachodu, przeł. Z. Żabicki, przedmowy Z. Żabicki, M.P. Markowski, Prószyński i S-ka, Warszawa 2004.

28 Por. uwagi na temat narracyjnej zasady metamorfozy w inspirującym szkicu Teresy Dobrzyńskiej poświęconym opowiadaniu Wiosna w Fialcie Vladimira Nabokova (T. Dobrzyńska, Tekst - styl - poetyka, Universitas, Kraków 2003, s. 57-106); wersja rozszerzona tego tekstu: taż, Opowiadanie Vladimira Nabokova "Wiosna w Fialcie” w kręgu możliwych wykładni sensu, [w:] Możliwość i konieczność w kulturze. Idee, narracje, interpretacje, red. red. B. Pawłowska-Jądrzyk, Wydawnictwo Naukowe UKSW, Warszawa 2017, s. 99-143. Nawiasem mówiąc, utwór Nabokova - tak odmienny w swym klimacie i literackim kształcie od Przemiany - zawiera motywy zbieżne z opowiadaniem Kafki, by wspomnieć tylko nadejście tytułowej wiosny, które wiąże znacząca koincydencja ze śmiercią bohaterki.

29 V. Nabokov, Wykłady o literaturze, s. 326.

30 Rosyjski pisarz kończy swoje obszerne studium na temat Przemiany następującymi słowami: „Zwróćcie uwagę na styl Kafki. Jego klarowność, jego precyzyjna i bardzo formalna intonacja stanowi uderzający kontrast z koszmarną treścią opowiadania. Żadne poetyckie metafory nie zdobią tej surowej, czarno-białej opowieści. Przejrzystość stylu uwypukla mroczne bogactwo tej fantazji. Kontrast i zgodność, styl i materia, maniera pisarska i fabuła łączą się tu w perfekcyjną całość" (V. Nabokov, Wykłady o literaturze, dz. cyt., s. 326). 
Do głównych motywów tematycznych najsłynniejszego opowiadania Kafki zaliczył autor Lolity motyw drzwi - „ich ciągłe otwieranie i zamykanie”31. Śledząc historię Gregora, jesteśmy nieprzerwanie świadomi istnienia drzwi (w pokoju byłego komiwojażera jest ich aż troje, tyle ile pokoi w mieszkaniu Samsów) ${ }^{32}$, przez jakiś czas wiążemy z nimi jakąś nieokreśloną, ostatecznie płonną nadzieję na możliwość koegzystencji dwóch połówek tego „rozpękniętego” świata, co wydaje się lustrzanym odbiciem pragnień i złudzeń samego Gregora. Motyw drzwi - nader konkretny, w naturalny sposób umotywowany w świecie przedstawionym utworu i pozostający w ścisłym związku z motywem ścian - sprzyja stematyzowaniu kwestii otwartości/zamkniętości świata, a zatem uwypukleniu problemów wolności i zniewolenia człowieka, uległości i dominacji ${ }^{33}$.

W odbiorze Przemiany jaskrawa absurdalność przedstawionych sytuacji nabiera wyjątkowej „siły rażenia” dzięki wpisaniu obrazowo ukazanego dramatu byłego komiwojażera w prozaiczną, drobiazgowo opisaną, bliską poniekąd każdemu scenerię. „Ontologiczny skandal”, który przesądza o upodleniu, alienacji i śmierci Gregora, dokonuje się wśród osób mu najbliższych, w czterech ścianach jego własnego pokoju, którego realności (w obrębie świata przedstawionego) nie sposób kwestionować. Predylekcja pisarstwa Kafki do szczegółowości i prozaiczności bywa interpretowana jako „drwina - zarówno z realizmu, jak i z alegorii”, co wiąże się z niemożnością krystalizacji na kartach jego utworów jednoznacznego, ogólnego przesłania ${ }^{34}$. Podobnie rzecz się ma z symboliczną wykładnią poszczególnych motywów, w tym przestrzennych. Rola tych ostatnich jest istotna - wszak pozwalają wyrazić realność i dotkliwość koszmaru, przedstawić inwazję absurdu w przestrzeń świata, który - mimo pozorów zwyczajności - na naszych oczach wyobcowuje się i przekształca w pułapkę. Nader łatwo zaciera się tu granica mię-

31 Tamże, s. 343, $363 \mathrm{i}$ inne.

32 Nabokov w pierwszym rzędzie podkreśla znaczenie liczby trzy w Przemianie (tamże, s. 362).

33 Autor książki Fiction of the Modern Grotesque dowodzi, że do najistotniejszych we współczesnej grotesce literackiej należą problemy uległości i dominacji, a to właśnie Kafka bodaj jako pierwszy przekroczył próg groteski współczesnej, przedstawiając postać, która "nie tylko potrafi stać się robakiem, ale w istocie st a je si ę nim" (B. McElroy, Fiction of the Modern Grotesque, The Macmillan Press LTD, Houndmills, Basingstoke, Hampshire and London 1989, s. 29; podkreślenie autora).

34 „Problem dziwacznego spiętrzenia szczegółów, które co jakiś czas pojawia się w prozie Kafki, kazał mi zadać pytanie o realistyczny, symboliczny bądź alegoryczny charakter tego pisarstwa. Dowodziłem, że żadne z tych określeń nie stosuje się zbyt dobrze do Kafki, i że między innymi to właśnie owa szczegółowość sprawia, że Kafkowskie historie są całkowicie odrealnione, zarazem jednak nie są w stanie przekazać spójnego alegorycznego pouczenia. Sądzę zatem, że szczegółowość jest u Kafki gorzką drwiną - zarówno z realizmu, jak i z alegorii" (A. Lipszyc, Szczegół i nieczytelność. Esej o negatywnej hermeneutyce Kafki, [w:] Poetyka egzystencji. Franz Kafka na progu XXI wieku, s. 171). 
dzy schronieniem a więzieniem (zob. przemiany znaczeń przestrzeni ograniczanej ścianami pokoju Gregora), zaś pogłosy odwiecznych metafizycznych tęsknot człowieka wybrzmiewają karykaturalnie (zob. ironiczne ujęcie kulturowo utwierdzonej opozycji góra - dół we fragmentach osnutych wokół motywów sufitu i podłogi). Kafka rzeczywiście nie odsłania sensu historii Gregora Samsy, pozwala nam jednak ten sens przeżyć i przeczuć - jako treść naszego własnego życia.

\section{Bibliografia}

Auerbach Erich, Blizna Odyseusza, [w:] Erich Auerbach, Mimesis. Rzeczywistość przedstawiona $w$ literaturze Zachodu, przeł. Zbigniew Żabicki, przedmowy Zbigniew Żabicki, Michał Paweł Markowski, Prószyński i S-ka, Warszawa 2004, s. 29-48.

Bergson Henri, Śmiech. Esej o komizmie, przeł. Stanisław Cichowicz, Wydawnictwo KR, Warszawa 1995.

Bettelheim Bruno, Cudowne i pożyteczne. O znaczeniach i wartościach baśni, przeł. i oprac. Danuta Danek, Wydawnictwo W.A.B., Warszawa 1996.

Blanchot Maurice, Wokót Kafki, przeł. Krzysztof Kocjan, Wydawnictwo KR, Warszawa 1996.

Camus Albert, Nadzieja i absurd w dziele Franza Kafki, [w:] Albert Camus, Mit Syzyfa $i$ inne eseje, przeł. Joanna Guze, Wydawnictwo Muza, Warszawa 1999, s. 150-161.

Dobrzyńska Teresa, Opowiadanie Vladimira Nabokova „Wiosna w Fialcie” w kręgu możliwych wykładni sensu, [w:] Możliwość i konieczność w kulturze. Idee, narracje, interpretacje, red. B. Pawłowska-Jądrzyk, Wydawnictwo Naukowe UKSW, Warszawa 2017, s. 99-143.

Dobrzyńska Teresa, Tekst - styl - poetyka, Universitas, Kraków 2003.

Gołaszewska Maria, Ozjawisku przemiany, [w:] Nauka o pięknie. Rozprawy z pogranicza estetyki, aksjologii ogólnej i antropologii filozoficznej, red. Maria Gołaszewska, Wydawnictwo Uniwersytetu M. Curie-Skłodowskiej, Kraków-Lublin 1990, s. 53-64.

Janion Maria, Żyjąc tracimy życie, Wydawnictwo W.A.B., Warszawa 2001.

Kafka Franz, Cztery opowiadania. List do ojca, przeł. Juliusz Kydryński, Jarosław Ziółkowski, Państwowy Instytut Wydawniczy, Warszawa 2003.

Kasperski Edward, Tragigroteska Kafki, „Tekstualia” 2008, nr 3, s. 19-34.

Kayser Wolfgang, Próba określenia istoty groteskowości, przeł. Ryszard Handke, „Pamiętnik Literacki" 1979, z. 4, s. 271-280.

Kopaliński Władysław, Stownik symboli, Wiedza Powszechna, Warszawa 1990.

Kundera Milan, Sztuka powieści, przeł. Marek Bieńczyk, „Czytelnik”, Warszawa 1998. Kwiatkowski Jerzy, Daniel Mróz, Wydawnictwo Literackie, Kraków 1961.

Lichaczow Dmitrij S., Świat wewnętrzny dzieła literackiego, przeł. Jerzy Faryno, „Pamiętnik Literacki" 1974, z. 4, s. 253-267. 
Lipszyc Adam, Szczegót i nieczytelność. Esej o negatywnej hermeneutyce Kafki, [w:] Poetyka egzystencji. Franz Kafka na progu XXI wieku, red. Edward Kasperski, Tomasz Mackiewicz, Wydawnictwo Uniwersytetu Warszawskiego, Warszawa 2004, s. 163-173.

Maciąg Włodzimierz, Nasz wiek XX: przewodnie idee literatury polskiej 1918-1980, Ossolineum, Wrocław 1992.

McElroy Bernard, Fiction of the Modern Grotesque, The Macmillan Press LTD, Houndmills, Basingstoke, Hampshire and London 1989.

Mieletinski Eleazar, Poetyka mitu, przeł. Józef Dancygier, przedmowa Maria Renata Mayenowa, Państwowy Instytut Wydawniczy, Warszawa 1981.

Morawiec Arkadiusz, Konstrukcja i znaczenie przestrzeni przedstawionej w powieściach Franza Kafki, Wydawnictwo Uniwersytetu Łódzkiego, Łódź 2000.

Nabokov Vladimir, Anna Karenina, [w:] Vladimir Nabokov, Wykłady o literaturze rosyjskiej, przeł. Zbigniew Batko, Wydawnictwo Muza, Warszawa 2002.

Nabokov Vladimir, Wykłady o literaturze, przeł. Zbigniew Batko, Wydawnictwo Muza, Warszawa 2001.

Nalewajk Żaneta, Ironia jako alternatywa rozpaczy. Krytyka kultury w „Sprawozdaniu dla Akademii”, „Tekstualia” 2008, nr 3, s. 67-77.

Pawłowska-Jądrzyk Brygida, Haneke w polu kontekstów fakultatywnych. „Miłośc” $z$ Kafka $w$ tle, [w:] Rozjaśnianie Hanekego, red. Brygida Pawłowska-Jądrzyk, Katarzyna Taras, Wydawnictwo Naukowe UKSW, Warszawa 2019, s. 167-186.

Pawłowska-Jądrzyk Brygida, Strategie pisarskie. „Przemiana”, [w:] Poetyka egzystencji. Franz Kafka na progu XXI wieku, red. Edward Kasperski, Tomasz Mackiewicz, Wydawnictwo Uniwersytetu Warszawskiego, Warszawa 2004.

Rainczak Wiktoria, Logiczność absurdu w twórczości Franza Kafki na podstawie „Przemiany” i „Procesu”, [w:] Komentarze do Kafki, red. Bartosz Małczyński, Jarosław Furmaniak, Wydawnictwo Chiazm, Wrocław 2007, s. 71-76.

Schulz Bruno, Posłowie do polskiego przekładu „Procesu” Franza Kafki [1936], [w:] Bruno Schulz, Szkice krytyczne, opracowanie i posłowie Małgorzata Kitowska-Łysiak, Wydawnictwo UMCS, Lublin 2000, s. 22-25.

Thomson Philip, The Grotesque, Published by Methuen \& Co Ltd., London 1972.

Tomkowski Jan, Robak, „Więź” 1982, nr 11/12, s. 42-52.

Wydmuch Marek, Franz Kafka, „Czytelnik”, Warszawa 1982. 
Brygida Pawłowska-Jądrzyk

\section{Familiar spaces of absurdity}

Summary

The subject of analysis in the article is The Metamorphosis (1915) of Franz Kafka. The author attempts to capture various aspects of the Kafka space phenomenon in the context of the functioning of the wall / ceiling motif in this probably the most famous narrative of world literature. At the same time, the researcher treats Kafka's work as an unsurpassed pattern of artistic scenery shaping: namely, which plasticity and concrete motifs and spatial relations make a kind of residuum of sublime, symbolic meanings, realizing fully only through the imagination of the recipient, in the course of contemplative reading and accompanying it aesthetic experience. The argument leads to the conclusion that in his parabolic, absurd, full of understatement (and yet surprisingly specific) piece of work, Kafka does not reveal the sense of the story of a hero transformed into an arthropod, but allows us to experience this sense and presage it - as the content of our own lives.

Keywords: Franz Kafka, The Metamorphosis, grotesque prose, absurdity, artistic imagination, depicted space, parabola, symbol

Brygida Pawłowska-Jądrzyk - doktor habilitowana nauk humanistycznych, profesor uczelni; Kierownik Katedry Poetyki Intersemiotycznej i Komparatystyki Mediów (Wydział Nauk Humanistycznych, Uniwersytet Kardynała Stefana Wyszyńskiego w Warszawie), redaktor naczelna czasopisma naukowego „Załącznik Kulturoznawczy". Jest badaczką o orientacji interdyscyplinarnej, specjalizuje się w zakresie poetyki i semiotyki tekstów kultury współczesnej (zwł. literatury, filmu, reklamy). Opublikowała m.in. monografie autorskie (Sens $i$ chaos $w$ grotesce literackiej, 2002; Uczta pod Wisząca Skała. Metafizyczność i nieokreśloność w sztuce (nie tylko) literackiej, 2011; Zarys poetyki uwodzenia. O strategiach perswazyjnych $w$ reklamie wizualnej, 2021) oraz dziesiątki artykułów w czasopismach naukowych i książkach zbiorowych. Redaktor i współredaktor monografii zbiorowych, w ostatnich latach: Fotoesej. Testowanie granic gatunku (2016); Ciężar i lekkość w kulturze. Estetyka, poetyka, style myślenia (2016); Rzecz w kulturze (2016); Możliwość i konieczność $w$ kulturze. Idee, narracje, interpretacje (2017); Śmierć w wodzie i inne motywy akwatyczne w horyzoncie wyobraźni (2018); Rozjaśnienie Hanekego (2018); Fotoesej. (Nie)widoki cudzego cierpienia (2019); Rejony twórczej zmiany. Tekst. Adaptacja. Medialna re-kreacja (2019); Przezroczystość w kulturze (2020); Ogień. Siła żywiołu - moc symbolu - potęga wyobraźni (2020); Hitchcock. Teksty i parateksty (w druku). 